JKEP

Vol 5, No 2, November 2020

ISSN: 2354-6042 (Print)

ISSN : 2354-6050 (Online)

\title{
Perspektif Perawat Ruangan tentang Caring dalam Merawat Pasien Kanker yang Menjalani Kemoterapi
}

\author{
Made Indra Ayu Astarini, M.T Arie Lilyana, Ninda Ayu Prabasari \\ Widya Mandala Catholic University Surabaya,, Pakuwon City, Surabaya, Indonesia \\ Email :madeayu@ukwms.ac.id
}

\author{
Artikel history \\ Dikirim, Aug 04 ${ }^{\text {th }}, 2020$ \\ Ditinjau, Nov 03 ${ }^{\text {th }}, 2020$ \\ Diterima, Nov $28^{\text {th }}, 2020$
}

\begin{abstract}
Cancer patients undergoing chemotherapy have a certain degree of dependence. Nurses are present as service providers with caring experiences. Nurses' perception of caring is limited to the technical aspects of care. The purpose of this study is to explore nurse's perspectives on caring behavior in treating cancer patients undergoing chemotherapy. The design of this study is a qualitative research. The participants were five nurses who directly involved in chemotherapy services. The sampling technique was purposive sampling. Data collection was carried by conducting in-depth interviews. The data collected were then analized according to the theme by Interpretative Phenomenological Analysis (IPA) and objectives of the study. This study has been approved in legal and ethic. Based on the results of the theme analysis, there are three themes namely caring understanding, forms of caring for cancer patients undergoing chemotherapy, and the benefits of caring. Nurses' perceptions about forms of caring behavior for cancer patients undergoing chemotherapy are establishing relationships, conducting assessments, providing care that patients need and providing education related to patient health. This study recommends to provide information for nurses about nurse caring behavior that can be applied to cancer patients undergoing chemotherapy, so that nurses can improve caring behavior in patients.
\end{abstract}

Keywords: Cancer patients; Caring; Nurses

\begin{abstract}
ABSTRAK
Pasien kanker yang menjalani kemoterapi memiliki tingkat ketergantungan tertentu. Perawat hadir sebagai pemberi pelayanan dengan pengalaman caring. Persepsi perawat tentang caring sebatas tentang aspek teknis perawatan. Tujuan penelitian ini adalah untuk mengeksplorasi perspektif perawat tentang perilaku caring perawat ruangan dalam merawat pasien kanker yang menjalani kemoterapi. Desain penelitian ini adalah penelitian kualitatif. Partisipan penelitian sebanyak 5 perawat dengan kriteria terlibat langsung dalam pelayanan kemoterapi. Teknik sampling dengan purposive sampling. Pengumpulan data dilakukan sampai data tersaturasi dengan cara melakukan wawancara mendalam. Data hasil wawancara kemudian dilakukan analisis tematik dengan metode Interpretative Phenomenological Analysis (IPA) sesuai dengan tujuan penelitian.
\end{abstract}


Penelitian ini sudah laik etik. Berdasarkan hasil analisi tema dari data yang didapat terdapat 3 tema yaitu pemahaman caring, bentuk caring pada pasien kanker yang menjalani kemoterapi, dan manfaat caring. Persepsi perawat tentang bentuk perilaku caring dalam merawat pasien kanker yang menjalani kemoterapi adalah menjalin hubungan, melalukan pengkajian, memberikan perawatan yang dibutuhkan pasien dan memberikan edukasi yang berkaitan dengan kesehatan pasien. Rekomendasi penelitian adalah memberikan informasi bagi perawat tentang perilaku caring perawat yang dapat diterapkan pada pasien kanker yang menjalani kemoterapi, sehingga perawat dapat meningkatkan perilaku caring pada pasien.

Kata kunci: Caring; pasien kanker; perawat

\section{PENDAHULUAN}

Kanker merupakan sel yang tumbuh secara autonom dan tidak terkendali dan kemudian dapat menginvasi jaringan organ di sekitarnya dan berdampak pada gangguan organ tersebut (Kurniasari, et al, 2017). Pada kasus kanker, penderitaan yang dialami oleh penderitanya bukan hanya penderitaan fisik semata, namun penderitaan total yang meliputi berbagai aspek, yaitu: penderitaan fisik, masalah psikologis, kesulitan sosial, faktor-faktor kultural dan spiritual. Kasus kanker stadium lanjut, yang terdiri dari stadium IVA dan IVB, penderitaan total ini akan semakin berdampak buruk terhadap status kesehatan penderita seiring dengan progresivitas penyakit kanker yang sudah lanjut. Kualitas hidup penderita juga akan menurun drastis dan tingkat ketergantungan mereka terhadap orang lain akan semakin tinggi.
Berdasarkan data dari Global Cancer Observatory (2020), di Indonesia jumlah kasus kanker baru pada tahun 2018 sebanyak 348.809. Wanita lebih banyak menderita kanker dibanding pria. Penderita kanker yang meninggal sebanyak 207.210, dimana tingkat kematian mencapai $84,1 \%$. Jenis kanker yang paling banyak pertama adalah kanker payudara $(16,7 \%)$, kedua kanker leher rahim $(9,3 \%)$, dan yang ketiga adalah kanker paru $(8,6 \%)$.

Pengobatan kanker dapat berupa pemberian kemoterapi. Kemoterapi dapat sebagai terapi utama, terapi ajuvan (tambahan), dan terapi paliatif (untuk stadium lanjut) (Rostia, 2012). Namun pemberian kemoterapi memiliki banyak efek samping. Efek samping dapat muncul akibat kemoterapi yang tidak hanya membunuh sel kanker tetapi juga sel sehat yang membelah dengan cepat. Kemoterapi dapat menimbulkan 
efek samping berupa gangguan fisik seperti, mual, muntah, nyeri, nafsu makan menurun, rambut rontok, konstipasi, kehilangan rasa, dan neuropati perifer (Ambarwati dan Wardani, 2014). Efek samping yang muncul inilah yang dapat memperberat kondisi pada pasien kanker yang menjalani kemoterapi. Selain itu kemoterapi memberikan dampak paling negatif pada aspek kesejahteraan emosional (Putri, 2017).

Peran perawat sangat penting dalam memberikan asuhan keperawatan pada pasien kanker. Perawat berperan selama pemberian kemoterapi mulai dari pemeriksaan tanda-tanda vital, pemberian obat sebelum terapi, dan pemasangan intra vena line (Usolin, Falah and Dasong, 2018). Perawat dengan caring-nya memberikan pelayanan pada pasien dengan sepenuh hati untuk meringankan beban yang dirasakan oleh pasien kanker yang menjalani kemoterapi. Pasien menilai caring adalah bentuk sikap perawat yang ramah, cepat tanggap terhadap keluhan, dan mampu menjadi pendengar yang baik (Suryani, 2012), memberikan perhatian pada klien
(Lumbantobing, Susilaningsih and Dadi, 2020).

Karlou, Papathanassoglou, dan Patiraki (2015), mengatakan bahwa persepsi perawat, pasien dan care giver tentang perilaku caring adalah sama. Aspek teknis dalam perawatan dan penjaminan keselamatan merupakan inti dari caring. Perawat, pasien dan care giver, mempersepsikan pengetahuan tentang pemberian terapi, manajemen pemberian obat dan keterampilan dalam terapi adalah bentuk dari caring. Menurut Lumbantobing et al. (2018), perawat dan pasien memiliki persepsi yang cukup baik terhadap perilaku caring perawat dalam memberikan asuhan keperawatan. Caring digambarkan dalam bentuk penghargaan pada pasien tidak hanya perhatian semata atau suatu ekspresi emosi, tetapi lebih pada menghargai martabat pasien.

Perawat dan pasien dapat merasakan dampak positif dan manfaat dari perilaku caring yang diterapkan selama memberikan asuhan keperawatan. Perilaku caring perawat yang baik akan memberikan kepuasan pada klien (Hidayati, 2017). Penelitian ini 
bertujuan untuk mengeksplorasi perspektif perawat ruangan tentang perilaku caring dalam merawat pasien kanker yang menjalani kemoterapi. Penelitian ini akan menggali lebih dalam tentang perspektif caring perawat dengan pendekatan teori caring menurut

\section{K.M Swanson.}

\section{METODE}

Penelitian ini merupakan penelitian kualitatif, studi fenomenologi deskriptif. Temuan dideskripsikan untuk menguraikan perilaku perawat ruangan dalam merawat pasien kanker yang menjalani kemoterapi. Populasi dalam penelitian ini adalah semua perawat ruangan yang terlibat langsung dalam perawatan pasien kanker yang menjalani kemoterapi di Rumah Sakit Swasta di Malang. Besar sampel penelitian adalah 5 perawat ruangan yang sesuai dengan kriteria yaitu mampu berkomunikasi secara verbal, dan non-verbal, terlibat langsung dalam perawatan pasien kanker yang menjalani kemoterapi, dan mau terlibat dalam penelitian yang dibuktikan dengan informed consent. Pada partisipan ke-5 sudah terjadi saturasi data atau tidak ada penambahan data baru. Teknik sampling dalam penelitian ini adalah purposive sampling, yaitu menentukan sampel dengan kriteria tertentu. Peneliti menentukan sendiri kriteria sampelnya, kemudian menentukan sampel secara mandiri berdasarkan kondisi lapangan di Rumah Sakit.

Data dikumpulkan dengan teknik wawancara mendalam selama 20-45 menit dan dilakukan di ruangan subjek penelitian bertugas. Proses pengumpulan data dan validasi data dilakukan pada tanggal 25 Mei-20 Juli 2019. Teknik analisis data menggunkan teknik

Interpretative

Phenomenological Analysis (IPA) dengan tahapan (1) menuliskan transkip, (2) menguji konten, (3) mengembangkan tema, (4) mencari hubungan antar tema, (5) mencari pola pada jawaban setiap subjek. Peneliti melakukan validasi data dengan melakukan konfirmasi data yang telah ditranskripsikan kepada subjek penelitian. Penelitian ini sudah mendapatkan sertifikat laik etik dengan sertifikat No: 1417-KEPK dari Komisi Etik Penelitian Kesehatan, Fakultas Keperawatan Universitas Airlangga. 


\section{HASIL DAN PEMBAHASAN}

Tabel 1 Karakteristik Partisipan Penelitian

\begin{tabular}{lccccc}
\hline No & Jenis Kelamin & Usia & Pendidikan & Suku bangsa & Lama Bekerja \\
\hline P1 & Perempuan & 31 tahun & D3 & Jawa & 9 tahun \\
\hline P2 & Perempuan & 29 tahun & D3 & Jawa & 7 tahun \\
\hline P3 & Perempuan & 28 tahun & D3 & Jawa & 5 tahun \\
\hline P4 & Perempuan & 35 tahun & D3 & Jawa & 10 tahun \\
\hline P5 & Perempuan & 27 tahun & D3 & Dayak & 3 tahun \\
\hline
\end{tabular}

Berdasarkan tabel 1 di atas, partisipan dalam penelitian sebanyak 5 perawat pelaksana, berjenis kelamin perempuan, dan dengan pendidikan diploma (D3) keperawatan. Empat dari lima partisipan bersuku bangsa Jawa.

Peneliti menemukan 3 tema penelitian dari hasil analisis tematik terhadap hasil wawancara mendalam dengan 5 orang partisipan penelitian. Tema yang teridentifikasi yaitu:

1. Pemahaman caring dengan dua sub tema yaitu definisi caring dan sumber pemahaman caring.

2. Bentuk caring pada pasien kanker yang menjalani kemoterapi dengan 5 sub tema yaitu keyakinan (maintaining belief), mengetahui (knowing), kebersamaan (being with), tindakan yang dilakukan sesuai kompetensi (doing for), memungkinkan (enabling).

3. Manfaat caring bagi pasien dan perawat dengan dua sub tema yaitu manfaat bagi perawat dan bagi pasien.

\section{Pemahaman Caring}

Tema pemahaman tentang caring memiliki 2 sub tema yaitu definisi dari caring serta sumber pemahaman caring. Sub tema definisi didapatkan dari hasil wawancara dengan partisipan 2 dan 4. Definisi caring seperti yang diungkapkan partispan 4 sebagai berikut:

"Pendekatan perawat terhadap pasien, bagaimana kita bisa memposisikan bahwa kita perawat, kita juga bisa harus bersimpati dengan kondisi pasien, apalagi orang pasti tahu yah mbak, kalau saya kena kanker gitukan, kayak penyakit yang momok gitu yah, pastikan dia juga butuh kita rangkul, kita dekati, supaya beliaunya juga bisa bersemangat” (Partisipan 4). Partisipan 4 mengungkapkan pemahaman yang dimilikinya tentang 
caring adalah sikap peduli, memberikan perhatian, mendengarkan keluhan pasien dengan baik, perilaku atau tindakan yang baik dari seorang perawat kepada pasien yang dirawatnya. Hal ini sesuai dengan Firmansyah, Noprianty and Karana, (2019) yang menyatakan bahwa caring ditunjukkan dalam bentuk perhatian, rasa tanggung jawab pada asuhan keperawatan yang dilakukan pada klien, dan ketulusan dalam merawat klien. Partisipan 4 menyebutkan caring dapat dilaksanakan dalam tugasnya sebagai seorang perawat dengan cara meningkatkan kemampuan dirinya dalam merawat pasien kanker sesuai posisinya sebagai seorang perawat. Berdasarkan tugas dan tanggung jawabnya sebagai pemberi asuhan, maka perawat dituntut memiliki kemampuan membawa diri sesuai dengan tugasnya. Kendala yang dijumpai saat bertemu dengan pasien yang bermasalah misalkan pasien yang cerewet dan rewel diartikan sebagai bentuk tanggung jawab seorang perawat yang harus diterima selama masa perawatan di ruangan. Kendala yang dijumpai saat merawat pasien kanker yang menjalani kemoterapi dan memiliki manifestasi penyakit yang bervariasi, membutuhkan kemampuan khusus dari seorang perawat untuk menyelesaikan masalah pasien tersebut.

Sub tema ke 2 dari tema ini adalah sumber pemahaman caring yang dimiliki oleh partisipan.

"hmm.. ya waktu kuliah dulu kan kalo misalnya sikap kita ke pasien apalagi kalau pasien kemo kan kaya pasien khusus, yang pengobatannya apa lebih gak seperti yang pasien lain. ya dari diri sendiri aja, kan kadang ada perawat yang cuek gamau anu kan dari diri kita sendiri gimana menaggapi", (Partisipan 3).

Pemahaman yang dimiliki tersebut diperoleh berdasarkan pengalaman saat merawat pasien yang menjalani kemoterapi. Setiap pasien memiliki pribadi yang unik dan berbeda antara satu dengan lainnya. Sehingga masalah keperawatan yang muncul akibat kanker dan kemoterapi yang diterimanya terkadang berbeda, dan itu membutuhkan kemampuan khusus bagi seorang perawat dalam merawat dan mendampingi pasien.

Hasil penelitian tersebut sejalan dengan Potter \& Perry (2011), Caring merupakan suatu proses yang selalu ada 
dalam dinamika hubungan pasienperawat. Caring adalah perhatian perawat dengan sepenuh hati terhadap klien, suatu rasa peduli, hormat dan menghargai seseorang. Perawat mengerti caring sebagai suatu tindakan yang ditujukan untuk menolong pasien dalam memulihkan keadaannya maupun menolong pasien dalam memenuhi kebutuhan dalam perawatannya. Perawat memaknai caring sebagai tindakan perawat yang harus dilakukan dalam setiap proses keperawatan khususnya pada pasien dengan kebutuhan dasar khusus seperti pasien kanker.

Menurut Swanson (1991) dalam Febriana (2017) caring adalah proses seorang perawat memahami suatu yang berarti dalam hidup pasien, dimana perawat hadir secara emosional, memperlakukan orang lain seperti memperlakukan diri sendiri, memberikan informasi, membantu pasien dalam menajalani hidup dan memberi kepercayaan pasien dalam menjalani hidup. Hal ini sejalan dengan hasil penelitian dimana subjek penelitian mengatakan bahwa perilaku caring yang dilakukan sumber pemahamannya berasal dari pengalaman saat merawat pasien yang dalam tahap akhir atau mengalami penyakit kronik. Pemahaman yang diperoleh tidak dapat hanya berasal dari teori yang didapatkan dalam pendidikan tetapi untuk dapat menjadi sebuah pemahaman yang baik harus berasal dari kejadian yang bermakna sehingga dapat menjadi bagian penting dalam profesi sebagai seorang tenaga kesehatan.

\section{Bentuk Caring pada pasien kanker}

Tema kedua yang didapatkan pada hasil penelitian ini yaitu bentuk caring pada pasien kanker yang menjalani kemoterapi. Bentuk caring didapatkan 5 sub tema yaitu bentuk caring dalam mempertahankan keyakinan (maintaining belief), mengetahui (knowing), kebersamaan (being with), tindakan yang dilakukan sesuai kompetensi (doing for), memungkinkan (enabling). Hal tersebut sesuai dengan Swanson dalam Febriana (2017), ada strategi komponen caring yang berguna dan efektif yaitu 1) maintaining Belief yaitu adanya kepercayaan dan keyakinan seseorang, 2) knowing yaitu pengertian pemahaman tentang kondisi dan situasi klien, 3) being with yaitu bukan hanya hadir secara menyeluruh tetapi juga saling berkomunikasi, 4) 
doing for yaitu melakukan tindakan untuk orang lain atau memandirikan pasien dan 5) enabling yaitu memfasilitasi klien untuk melewati masa transisi dalam hidupnya.

Sub tema yang pertama yaitu bentuk caring dalam mempertahankan keyakinan oleh partisipan. Ungkapan partisipan sebagai berikut

"Sebisa mungkin seakrab mungkin yah mba, supaya mereka juga welcome ke kita” (Partisipan 4).

Ungkapan partisipan dalam sub tema ini adalah bagaimana kemampuan perawat dalam memahami kondisi pasien yang sedang menjalani kemoterapi dan efek yang mungkin ditimbulkan yang akan mempengaruhi kondisi pasien yang dapat dilihat dari perilaku, tutur kata, sikap tubuh dan kontak mata perawat, membina hubungan saling percaya antara perawat dan klien untuk memudahkan tindakan keperawatan.

Sejalan dengan hasil penelitian tersebut menurut Kalfoss dan Owe (2015) pada maintaining belief didasarkan pada pandangan humanistik dari seseorang menghormati perbedaan individu dan juga memahami perlunya menjaga keseimbangan yang harmonis antara seseorang.

Sub tema yang kedua yaitu bentuk caring dalam menggali informasi mengenai apa yang dirasakan pasien atau latar belakang penyakit pasien.

"Mungkin pas waktu saat kita tindakan sekaligus anamnesa ya itu kita lakukan caring itu mungkin nanyananya latar belakang keluarganya itu ada yang riwayatnya kanker apa enggak". (Partisipan 1).

"Waktu ke pasiennya masukkan obat, gitu kita kan nanya keluhannya apa bu ini, sudah mual apa belum?". (Partisipan 3).

Perawatan pasien kanker dengan kemoterapi, diperlukan pengkajian data dari segala aspek. Hal tersebut sesuai dengan Swanson dalam Febriana (2017) Knowing adalah mengetahui, dalam praktek keperawatan knowing adalah usaha untuk mencari tahu dan menambah ilmu pengetahuan, mengetahui arti dan kejadian dalam kehidupan, berbagai fenomena yang ada, dan proses berfikir dengan penuh rasa empati. Knowing juga dapat digambarkan dalam bentuk mencari informasi secara mendalam, tidak 
berasumsi serta memahami pengalaman hidup klien, peka terhadap apa yang diucapkan dan perilaku klien, berfokus pada tujuan keperawatan, melibatkan klien dan keluarga dalam proses perawatan.

Perawat menggunakan segala pengetahuannya untuk dapat meberikan pertolongan pada pasien. Perawat perlu mengetahui proses penyakit pasien untuk dapat memberikan asuhan keperawatan yang berkualitas. Perawat dapat memenuhi kebutuhan pasien jika perawat memiliki pengetahuan tentang penyakit yang sedang dirasakan pasien (Ferguson, 2018).

Sub tema yang ketiga yaitu bentuk caring dalam kebersamaan, hal ini dapat berupa tindakan perawat dalam menanggapi keluhan pasien dengan mendengarkan yang dirasakan pasien.

“Opo yo, biasanya kalo kita ga senyumin itu kan pasiennya, apa, ngeliat kita itu gaenak kan jadinya mbak. Jadi ya harus tersenyum (tertawa)" (Partisipan 2)

"Nanti kalau ada keluhan, mungkin cerita apa yah, jadi pendengar yang setia aja untuk mendengarkan keluhan mereka supaya mungkin mereka mau bercerita sama kita yah”. (Partisipan 4)
Ungkapan partisipan dalam sub tema ini yaitu bagaimana peran seorang perawat yang hadir secara utuh, mendengarkan pasien bukan hanya sekedar mendengar tetapi hadir menemani pasien dalam setiap keluhan yang di rasakan saat pasien menjalani kemoterapi. Menurut Swanson dalam Febriana (2017), being with yaitu tidak hanya hadir secara keseluruhan tetapi juga saling bercerita untuk saling berbagi tentang yang dirasakan klien tanpa membebani klien dan perawat memberikan dukungan dan kenyamanan serta meberikan perhatian secara fisik maupun emosional, serta berkomitmen untuk memberikan pelayanan dengan setia sebagai bentuk tanggung jawab dengan menghormati martabat klien secara utuh (Lumbantobing et al., 2018). Hal tersebut merupakan bukti kehadiran perawat dalam setiap keadaan pasien yang secara tidak langsung mendukung proses penyembuhan dari pasien yang dirawat.

Sub tema yang keempat yaitu bentuk caring dalam tindakan yang sesuai kompetensi yang berhubungan dengan tindakan mandiri atau kolaborasi dengan tenaga medis lainnya. 
"Iya melanjutkan kemoterapi, setelah inform ada pokoknya kita inform consent sekitar udah selesai kita pasang infus ya langsung obatnya datang kita masukkan kemoterapi." (Partisipan 2)

Menurut Swanson dalam Febriana (2017), doing for adalah sesuatu yag berkaitan dengan keterampilan perawat dalam melakukan praktik keperawatan dengan memperhatikan evidence based atau data yang mutakhir, memberikan kenyamanan klien, melakukan tindakan sesuai kompetensi, menjaga keselamatan klien dengan kedisiplnan, ketelitian dan kehati-hatian. Karlou, Papathanassoglou dan Patiraki (2015), mengungkapkan bahwa perawat memiliki persepsi yang baik tentang caring adalah yang berkaitan dengan pemberian terapi pada pasien, seperti pemberian obat. Hal ini sesuai dengan pernyataan partisipan bahwa bentuk dari caring menurut partisipan adalah melakukan tindakan seperti memasukkan obat kemoterapi.

Sub tema yang kelima yaitu bentuk caring dalam hal pemberdayaan dimana perawat dapat memberikan dukungan berupa informasi yang dapat meningkatkan kesehatan pasien.
"Jadi kita harus memberi penjelasan mereka, harus semangat jangan terlalu takut dulu harus dijalani kan ini untuk kesembuhan." (Partisipan $3)$.

Ungkapan partisipan dalam penelitian ini yaitu tindakan yang dilakukan perawat dalam membantu pasien untuk mendapatkan informasi yang ingin diketahui pasien seputar kemoterapi pada pasien kanker baik tentang kondisi tubuh ataupun hal lain yang ingin diketahui oleh pasien yang berhubungan dengan kesehatannya. Menurut Swanson dalam Febriana (2017), Enabling adalah faktor pemungkin atau empowerment. Perawat berperan sebagai fasilitator dalam usaha klien untuk menghadapi perubahan dalam hidup klien dengan memberikan edukasi, membantu menyelesaikan masalah, memberi dukungan, memvalidasi yang dirasakan klien, melakukan pembaruan pada intervensi keperawatan, dan berpikir positif serta mampu memberikan tanggapan yang sesuai saat kontak dengan klien. Hal ini juga dapat digambarkan melalui perilaku perawat menyadari akan kemampuannya untuk menolong klien secara sistematis (Darmini, Susanti dan Kamaryati, 2017). Menurut Kusnanto 
(2004), peran perawat sebagai Consultant, adalah perawat dapat menjadi sumber informasi bagi klien untuk membantu menyelesaikan masalah klien. Menurut Wahyuni (2015), kemampuan perawat berkomunikasi yang baik dan lebih memberikan perhatian adalah harapan bagi klien yang menjalani kemoterapi.

\section{Manfaat Caring}

Tema ke 3 yaitu manfaat caring yang didukung oleh sub tema manfaat yang dirasakan pasien dan manfaat yang dirasakan oleh perawat.

"Pasien lebih percaya ya sama kita, terus mungkin lebih tenang" (Partisipan 1)

"Kalo kita kasih semangat ke pasiennya kan bisa, pasiennya kan bisa welcome sama kita, bisa terbuka, bisa cerita-cerita terus kadanag juga untuk kembali lagi ke sini itu biasanya lebih semangat" (Partisipan 2).

Ungkapan partisipan dalam penelitian ini adalah tentang manfaat yang dirasakan pasien dan perawat dalam melaksanakan perilaku caring perawat. Manfaat bagi pasien yaitu pasien menjadi tidak takut saat menjalani kemoterapi, mempunyai rasa tenang, dan nyaman saat perawat melakukan tindakan kemoterapi. Manfaat untuk perawat adalah perawat merasa lebih mudah melakukan tindakan dengan adanya rasa percaya dari pasien terhadap tindakan keperawatan sebelum, saat, dan setelah pasien kemoterapi. Hal ini berbeda apabila belum terjalin rasa percaya kepada perawat, perawat akan sulit untuk melakukan tindakan keperawatan, seperti melakukan tindakan untuk mengurangi rasa mual ataupun komplikasi lain dari kemoterapi yang telah dilakukan. Hal inilah yang dipersepsikan partisipan sebagai manfaat dari perilaku caring yang telah dilakukan. Selain hal tersebut, komunikasi verbal maupun non-verbal yang dilakukan dengan baik saat melakukan tindakan, akan memudahkan pasien untuk datang kembali menjalani kemoterapi dan rasa percaya diri perawat juga meningkat. Motivasi perawat meningkat saat proses asuhan keperawatan yang dilakukan berjalan dengan baik dan pasien mempunyai kepuasan yang tinggi terhadap pelayanan yang diberikan.

Rasa senang yang diungkapkan perawat merupakan bentuk dari kepuasan perawat dalam memberikan asuhan 
keperawatan. Menurut Ilkafah and Harniah (2017), perilaku caring perawat berhubungan dengan kepuasan klien. Klien yang menilai perawat berperilaku caring dengan baik juga merasakan kepuasan yang tinggi. Perawat mengungkapkan rasa pencapaian kepuasan saat dapat memberikan pelayan pada pasien (Eldh et al., 2016).

Keterbatasan selama proses penelitian ini adalah pada saat proses pengumpulan data, partisipan sedang dalam periode waktu bekerja (di waktu dinas). Beberapa partisipan masih disibukkan dengan panggilan dari teman lain yang berkaitan dengan pelayanan pada pasien, sehingga perlu untuk difokuskan kembali pada pertanyaan yang sudah disusun.

\section{SIMPULAN}

Pemahaman caring perawat menggambarkan perspektif perawat tentang perilaku caring dalam merawat pasien kanker yang menjalani kemoterapi. Bentuk caring pada pasien kanker yang menjalani kemoterapi dipersepsikan dalam bentuk menjalin hubungan, melalukan pengkajian, memberikan perawatan yang dibutuhkan pasien dan memberikan edukasi yang berkaitan dengan kesehatan pasien. Manfaat caring bagi pasien adalah pasien memiliki semangat untuk tetap melanjutkan terapi dan manfaat caring bagi perawat adalah kepuasan dalam memberikan pelayanan. Rekomendasi penelitian bagi pelayanan keperawatan adalah perawat dapat meningkatkan perilaku caring bagi pasien kanker yang menjalani kemoterapi. Rekomendasi untuk penelitian selanjutnya adalah dapat mengeksplor lebih dalam tentang dampak dari melakukan perilaku caring, baik untuk perawat, pasien dan manajemen rumah sakit.

\section{UCAPAN TERIMA KASIH}

1. Kuncoro Foe, G.Dip.Sc., Ph.D., sebagai Rektor Universitas Katolik Widya Mandala Surabaya

2. Hartono Pranjoto, Ph.D., sebagai ketua LPPM Universitas Katolik Widya Mandala Surabaya.

3. Dr. dr. B. Handoko Daeng, Sp.KJ(K), sebagai Dekan Fakultas Keperawatan Universitas Katolik Widya Mandala Surabaya, yang telah memberi kesempatan untuk menyelesaikan laporan penelitian ini. 
4. Direktur Rumah Sakit tempat penelitian beserta seluruh perawat yang terlibat dalam penelitian ini.

5. Mahasiswa kami, Sabrina Noya, Dwi Reza, Irza R., Oktaviani Calvin yang telah membantu dalam proses verbatim penelitian.

\section{DAFTAR RUJUKAN}

Ambarwati, W. N. and Wardani, E. K. 2014. Efek Samping Kemoterapi Secara Fisik Pasien Penderita Kanker Serviks. (Online), (https://jurnal.unimus.ac.id/index.p hp/psn12012010/article/view/1428) diakses 8 November 2020 .

Darmini, A. A. A. Y., Susanti, N. L. P. D. and Kamaryati, N. I. P. 2017. Gambaran Kecerdasan Emosional dan Perilaku Caring Perawat di Rumah Sakit Daerah Badung, Bali., Jurnal Keperawatan Komprehensif. (Online), Jilid 3, No. 2, (http://journal.stikep-

ppnijabar.ac.id/index.php/jkk/articl e/view/90), diakses 6 November 2020.

Eldh, A. C. et al. 2016. "I have the world's best job" - staff experience of the advantages of caring for older people. Scandinavian Journal of Caring Sciences. (Online), Vol. 30, No. 2, (https://doi.org/10.1111/scs.12256) , diakses 13 November 2020.

Febriana, Diva Viya. 2017. Konsep Dasar

Keperawatan

(1).Yogyakarta: healthy. Chicago Style.

Ferguson, R. 2018. Ways of Knowing and Caring Used by Nurses in Community Hospice Agencies. Journal of Hospice and Palliative Nursing. (Online), Vol. 20, No. 1, (https://journals.lww.com/jhpn/Abs tract/2018/02000), diakses 13 November 2020.

Firmansyah, C. S., Noprianty, R. and Karana, I. 2019. Perilaku Caring Perawat Berdasarkan Teori Jean Watson di Ruang Rawat Inap. Jurnal Kesehatan Vokasional. (Online), Vol. 4, No. 1, (https://journal.ugm.ac.id/jkesvo/ar ticle/view/40957), diakses 6 November 2020.

Global Cancer Observatory. 2020. Indonesia. (Online), (https://gco.iarc.fr/today/data/factsh eets/populations/360-indonesiafact-sheets.pdf), diakses 8 November 2020.

Hidayati, N. 2017. Hubungan Perilaku Caring Perawat dengan Tingkat Kepuasan Pasien BPJS Di RSUD Dr. Rasidin Padang. Journal Endurance. (Online), Vol. 2, No. 2, (http://ejournal.lldikti10.id/index.ph p/endurance/article/view/1882), diakses 6 November 2020.

Ilkafah and Harniah. 2017. Perilaku Caring Perawat dengan Kepuasan Pasien di Ruang Rawat Inap Private Care Cantre RSUP Dr Wahidin Sudirohusodo Makassar. Jurnal Keperawatan. (Online), Vol. 8, No. 2 ,

(http://ejournal.umm.ac.id/index.ph p/keperawatan/article/view/4034), diakses 6 November 2020

Kalfoss, M., \& Owe, J. 2015. Empirical Verification of Swansons's caring Processes Found in Nursing 
Actions. Journal Of Nursing, Vol. 5: 976-986.

Karlou, C., Papathanassoglou, E. and Patiraki, E. 2015. Caring behaviours in cancer care in Greece. Comparison of patients', their caregivers' and nurses' perceptions. European Journal of Oncology Nursing, (Online), Vol. 19, No. 3, (https://www.sciencedirect.com/sci ence/article/pii/S146238891400194 X), diakses 13 November 2020.

Kurniasari, F.N., et al. 2017. Buku Ajar Gizi dan Kanker. Malang: UB Media.

Kusnanto. 2004. Pengantar Profesi dan Praktik Keperawatan Profesional. Jakarta: EGC.

Lumbantobing, V. et al. 2018. Persepsi Perawat, Pasien dan Masyarakat Umum tentang Perilaku Caring Perawat dalam Memberikan Asuhan Keperawatan di Bandung. Journal of Nursing Care \& Biomolecular. (Online), Vol. 3, No.

(http://www.stikesmaharani.ac.id/ ojs-

2.4.3/index.php/JNC/article/view/ 83), diakses 6 November 2020.

Lumbantobing, V. B., Susilaningsih, F. S. and Dadi, M. 2020. Perilaku Caring Perawat Pelaksana Rawat Inap Rumah Sakit di Kabupaten Indramayu. Jurnal Ilmiah Keperawatan Sai Betik. (Online), Vo. 15, No. 2, (https://ejurnal.poltekkestjk.ac.id/index.php/JKEP/article/vi ew/1379), diakses 6 November 2020

Potter, P. A \& Perry, A. G., 2011. Fundamental Jakarta: EGC

Keperawatan.

Putri, R. H. (2017). Kualitas Hidup Pasien Kanker Ginekologi yang Menjalani Terapi. Jurnal Aisyah: Jurnal Ilmu Kesehatan. (Online), Vol. 2, No. 1, (https://aisyah.journalpress.id/index .php/jika/article/view/34), diakses 6 November 2020

Rostia. 2012. Solusi Cerdas Mencegah dan Mengobati Kanker. Jakarta: AgroMedia Pustaka.

Suryani, M. 2012, Hubungan Lingkungan Kerja dengan Perilaku Caring Perawat di RS PGI Cikini Jakarta. Tesis, Jakarta: Universitas Indonesia.

Usolin, D. N., Falah, F., \& Dasong, S. 2018. Persepsi Perawat Pelaksana tentang Manajemen Kemoterapi pada Pasien Kanker di RS Ibnu Sina Makassar. Jurnal Ilmiah Kesehatan Diagnosis. (Online), Vol. 12, No. 2, (http://ejournal.stikesnh.ac.id/index .php/jikd/article/view/290), diakses 6 November 2020

Wahyuni, D., Huda, N., \& Utami, G. T. 2015. Studi Fenomenologi: Pengalaman Pasien Kanker Stadium Lanjut yang Menjalani Kemoterapi. Jom, 2 (2): 1041-1047. 